THÉMATA. Revista de Filosofía

$\mathrm{N}^{\mathrm{o}} 51$, Enero-junio (2015) pp.: 227-246

ISSN: 0212-8365 e-ISSN: 2253-900X

doi: $10.12795 /$ themata.2015.i51.12

\title{
KAIRÓS, EL INSTANTE DECISIVO
}

\author{
KAIROS, THE DECISIVE MOMENT
}

Maria Gilabert Tormo ${ }^{1}$

Universitat de València (España)

Recibido: 01-04-2014

Aceptado: 30-12-2014

Resumen: En este artículo haremos un recorrido conceptual por el término y las problemáticas de la fotografía, utilizando la figura de Cartier-Bresson como hilo conductor. Tras intentar determinar las características que la definen, analizaremos la relación de la misma con la pintura; trataremos de ver, a continuación, diferentes opiniones y posturas acerca de si puede o no considerarse arte; y apuntaremos, en última instancia, ciertos cambios en el concepto de belleza que ha conllevado esta nueva forma de reproducir el mundo. Palabras-clave: instante decisivo, kairós, Cartier-Bresson, arte, lo bello.

\begin{abstract}
In this article we will explore the concept and problems of photography, using the figure of Cartier-Bresson as the thread that runs through the entire essay. After trying to determine the characteristics that define it, we will analyses the relationship between photography and painting. Then, we will attempt to see the different opinions and points of view about whether photography can or cannot be considered art. Finally, we will state certain changes in the concept of beauty that has led to this new way of reproducing the world.
\end{abstract}

Key-words: decisive instant, kairós, Cartier-Bresson, art, beauty.

\section{Del Kairós al instante decisivo.}

El instante decisivo es una expresión que pertenece a una tradición de pensamiento artístico influenciada por el filósofo alemán G. E. Lessing y su análisis de Laocoonte según el cual «la genialidad del artista consiste en percibir y luego transcribir el apogeo de una situación $»^{2}$. El instante decisivo

[1] (mari_a_eta@hotmail.com) Licenciada en Filosofía (Universitat de València), ha sido becaria Erasmus en Holanda en Rijksuniversiteit Groningen y becaria Séneca en la Universidad del País Vasco.

[2] Chéroux, C., Henri Cartier-Bresson, el disparo fotográfico, traducción de Laura Collet Texidó, 
es, así pues, un momento preciso en el que «las cosas se organizan en una disposición a la vez estética y significativa»; es un equilibrio formal que «revela la esencia de una situación $»^{3}$. En fotografía, este momento decisivo comprende dos elementos: por un lado, debe tener un contenido significativo, debe dar testimonio de la condición humana; y, por otro, debe adecuarse a una composición rigurosa.

Pero este concepto proviene de uno más antiguo, propio de la Grecia Clásica: el kairós. Este concepto, originariamente, se relaciona con «el momento adecuado, oportuno, el instante propicio. Es una elección que se realiza en la temporalidad», pero "era un lugar en el tiempo que también designaba un lugar decisivo» ${ }^{4}$. Con el tiempo, pasó a relacionase con la "acepción de ocasión propicia, de momento que no hay que dejar pasar, de decisión que hay que saber tomar ${ }^{5}$. Así, este concepto griego pasa de relacionarse con la extensión, para luego restringirse al instante; paso que tuvo que ver con la aparición en Grecia de las bellas artes.

Por otro lado, el kairós también se opone al logos «cuando rompe su noble continuidad»; así como al tuché o azar, porque «es la decisión correcta [...], un punto de equilibrio [...] que hace oscilar el orden de los fenómenos» ${ }^{6}$.

Por tanto, el kairós, en la acción del fotógrafo, «es tanto el hecho de alcanzar el objetivo en el espacio como el de llegar en el momento oportuno en el tiempo» ${ }^{7}$, es «un arte de la previsión y de la precisión» ${ }^{8}$.

\section{La fotografía:}

\subsection{Historia para una definición de fotografía.}

Obviando el hecho de que, en 1939, Daguerre presenta su primer $d a$ guerrotipo y de que no es hasta el año siguiente cuando en Francia e Inglaterra aparecen las primeras máquinas fotográficas, otro acontecimiento relevante en la historia de la fotografía es la invención, en 1882, del obturador de cortinilla a manos de Ottomar Anschütz. Este invento hizo posible la fotografía instantánea o snapshot, que permite reducir el tiempo de posado y obtener una fotografía accesible cuyos resultados suelen exponerse en los salones y paredes de las cosas. Aunque no todas las opiniones respecto a estos avances fueron fa-

Blume, Barcelona, 2012, p. 99.

[3] Ibídem, p. 98.

[4] Ibídem, p. 47.

[5] Ídem.

[6] Ibídem, p. 51.

[7] Ídem.

[8] Ibíem, pp. 53-54.

THÉMATA. Revista de Filosofía, No 51 enero-junio (2015) pp.: 227-246 doi: 10.12795/themata.2015.i51.12 
vorables, como es el caso de una declaración hecha por Brecht en Tentativas, en la que afirma que el perfeccionamiento de los aparatos fotográficos no es más que un atraso, puesto que el resultado es "sin duda de mucha menos calidad»; típico comentario que nos recuerda al tópico 'cualquier tiempo pasado fue mejor', muy habitual en el entorno de la fotografía.

Sea como fuere, la fotografía aparece como una nueva ética de la visión que entraña un nuevo código visual que altera y amplía las nociones de lo que merece la pena mirar. Con expresiones de uso cotidiano tales como 'estás para una foto', se muestra que «la omnipresencia de las cámaras insinúa de modo persuasivo que el tiempo consiste en acontecimientos interesantes, dignos de ser fotografiados» ${ }^{10}$.

Además, conlleva grandes avances gracias a sus características: las fotos son objetos de producción barata, que se transportan, acumulan y almacenan fácilmente; son fáciles de reducir, ampliar, recortar, retocar y manipular. La fotografía también es adquisición, en tanto que nos permite poseer, de algún modo, a una persona o cosa querida; y es una forma de establecer relaciones de consumo y de obtener información. La fotografía, por tanto, re-define la realidad.

Comporta, por otro lado, la ruptura entre dos categorías de imágenes: las realizadas a mano (la pintura o el dibujo) y las creadas mecánicamente por el efecto de la luz en una película sensible. Si bien el valor de las primeras reside en que son una obra única; el de las segundas, en tanto que susceptible de reproducción, reside en el hecho de captar el momento único.

La acción fotográfica puede interpretarse de dos maneras: o bien considerándola como un acto de conocimiento lúcido y preciso, o bien como una manera de encuentro intuitivo. Esta segunda forma correspondería a la utilizada por Cartier-Bresson, que afirma que "hay que pensar antes y después [...], jamás mientras se hace la fotografía ${ }^{11}$. Esta es una idea bastante difundida entre los fotógrafos: no sirve disparar fotografías indiscriminadamente con la intención de que alguna salga correctamente, sino que, "para hacer una buena fotografía [...], se ha de haber visto de antemano» ${ }^{12}$. De este modo se refleja la idea de que el papel de la máquina en fotografía es secundario, pues prima ante todo la acción humana y su necesidad de desvelar una realidad que está oculta.

La fotografía puede ser edificante, porque retiene y mejora la capacidad de observación y transforma la vida, así como contener la humanidad del momento fotografiado. En ambos casos, el fotógrafo es una especie de observador ideal que toma distancia respecto a aquello que lo rodea.

Otra de sus características es que permite hacer cercanas cosas lejanas

[9] Benjamin, W.: op. cit., p. 136.

[10] Sontag, S., Sobre la fotografía, traducción de Carlos Gardini, Debolsillo, Barcelona, 2013, p. 22.

[11] Ibídem, p. 116.

[12] Ibídem, p. 117.

THÉMATA. Revista de Filosofía, $\mathrm{N}^{\circ} 51$ enero-junio (2015) pp.: 227-246

doi: 10.12795/themata.2015.i51.12 
o poco familiares, como la muerte o los paisajes; hasta el punto de que, cuando conocemos el mundo a través de imágenes, «a la gente a menudo le causa decepción, sorpresa o indiferencia la realidad» ${ }^{13}$, pues "somos vulnerables ante los hechos perturbadores en forma de imágenes fotográficas como no lo somos ante los hechos reales» ${ }^{14}$. Por ello afirmamos que la fotografía no se limita a reproducir la realidad, la 'recicla' en tanto que da nuevos significados a las cosas y a los acontecimientos. En definitiva, determina qué es 'interesante'.

Por sus características, la fotografía ha conllevado la moda, cada vez más extendida, de considerar la cámara como un compañero de viaje indispensable, que da cuenta ante aquellos que no estuvieron presentes de cómo se desarrollaron los acontecimientos vividos en su ausencia.

Por su parte, Susan Sontag afirma que la fotografía es «un rito social, una protección contra la ansiedad y un instrumento de poder» ${ }^{15}$. Así muestra que, la intromisión de la fotografía en la vida cotidiana, la ha convertido en una especie de rito social que, paulatinamente, se ha ido introduciendo en cualquier evento para dejar constancia del mismo. De este modo, la fotografía consigue reducir esa ansiedad y nostalgia que el paso del tiempo, y de las personas, suele conllevar. Si bien la gente ya no ve la fotografía como algo mágico, que roba el alma de las personas que en ellas aparecen, sí es cierto que algo de este misticismo se mantiene, por ejemplo, en la resistencia a romper o tirar la fotografía de un ser querido, especialmente si ya no está.

El problema que conlleva esta intromisión en la dimensión social es que la fotografía ha llegado a convertirse en algo compulsivo, hasta tal punto que, parafraseando aquello que Mallarmé afirmó en el siglo XIX con respecto a los libros, parece que todo existe para culminar en una fotografía. A parte del carácter compulsivo, otro problema es su relación con el tiempo: por un lado, inventan la inmortalidad (pues son testigo del envejecimiento de las personas) y, por otro lado, invitan al sentimentalismo (pues recuerdan la muerte y el paso del tiempo).

Además de ser parte del rito social, la fotografía también es un instrumento de poder: pasa a formar parte de los procesos burocrático porque permite transmitir información; es usada por los Estados como instrumento de vigilancia y control porque permite procurar pruebas; a la vez que sirven para dar cuenta de que algo sucedió.

Es así, por tanto, un instrumento de manipulación ideológica; puesto que, si bien no es capaz de construir una moralidad, sí puede ayudar a su construcción y consolidación. La fotografía rememora acontecimientos, mientras la ideología determina qué momentos deben ser recordados. Un inconveniente

[13] Ibídem, p. 163.

[14] Ibídem, p. 164.

[15] Ibídem, p. 18.

THÉMATA. Revista de Filosofía, No 51 enero-junio (2015) pp.: 227-246 doi: 10.12795/themata.2015.i51.12 
a este respecto es que, después de una exposición repetida a las imágenes, el acontecimiento pierde realidad; es decir, el impacto ante las atrocidades se desgasta con el uso de la imagen fotográfica. Por tanto, «la fotografía 'comprometida' ha contribuido a adormecer la conciencia, tanto como a despertarla ${ }^{16}$.

Otra consecuencia negativa es la no participación asociada a la fotografía, especialmente en el ámbito del fotoperiodismo contemporáneo, en el que se ha vuelto lícito optar por la fotografía en un momento crítico en el que la actuación del fotógrafo podría salvar una vida. Este hecho también se asociado a los países capitalistas, en los que el arte nos acostumbra a cosas que antes no éramos capaces de soportar; la fotografía, por ejemplo, reduce los escrúpulos morales y sensoriales.

No obstante, «aunque incompatible con la intervención física, el empleo de la cámara sigue siendo un modo de participación $»^{17}$ puesto que, por ejemplo, este tipo de reportaje fotográfico puede incidir en la conciencia social y promover cambios, ya que no permiten al espectador mantener la distancia. La fotografía, como afirmó Luís Buñuel con respecto al cine, puede mostrar que "'este no es el mejor de los mundos posibles'» ${ }^{18}$.

Pese a todo, hay que remarcar que, en sus orígenes, cuando la lectura no era un hábito extendido, fue útil la introducción de imágenes en los periódicos para hacer accesible la información; pues en un reportaje, "los pies de foto deben ser el contexto verbal de las imágenes» ${ }^{19}$.

En todo esto queda implícita una idea ya muy repetida: fotografiar es conferir importancia a las cosas. A este hecho de que no hay momento, ni persona, más importante que otro, lo denominamos democratización de la fotografía, pues es un instrumento accesible (económico, fácil de transportar) para todo el mundo que sirve para 'inmortalizarlo’todo. Es más, como afirmó Cartier-Bresson en una entrevista concedida a la revista Manchete en marzo de 1969, "desde el punto de vista de la fotografía, todo el mundo es un artista en potencia» ${ }^{20}$; es decir, "lo que antes sólo veía un ojo muy inteligente, ahora lo puede ver cualquiera $»^{21}$ pues "nadie exige que la fotografía sea culta» ${ }^{22}$. En definitiva, se asimila el imperativo whitmaniano de acuerdo con el cual hay que «tratar todos los momentos como si tuvieran la misma importancia» ${ }^{23}$.

Además, permite eliminar las desigualdades: es un lenguaje que todo

[16] Ibídem, p. 30.

[17] Ibídem, p. 22.

[18] Ibídem, p. 42.

[19] Chéroux, C.: op. cit., pp. 136-137.

[20] Ibídem, p. 141.

[21] Sontag, S.: op. cit., p. 103.

[22] Ibídem, p. 39.

[23] Ibídem, p. 45.

THÉMATA. Revista de Filosofía, №51 enero-junio (2015) pp.: 227-246 doi: 10.12795/themata.2015.i51.12 
el mundo entiende y permite acercar las diferentes culturas y naciones sin necesidad de influencias políticas. De acuerdo con Helmut Gernshein, con las fotografías «nos transformamos en testigos presenciales de la humanidad e inhumanidad del género humano» ${ }^{24}$ puesto que son, según Paul Strand, un registro de las vidas de las personas que nos permite ver las costumbre de otros e influenciarnos por ellas.

La fotografía también elimina la desigualdad de clases que marcaban los cuadres a los que sólo unos pocos tenían acceso. Por un lado, permite que cualquiera sea retratado y, por otro, permite que cualquiera, independientemente de su condición, pueda realizarlas o adquirirlas; y suelen ser más de una, de modo que degradan más que magnifican.

La fotografía es a la vez «una pseudopresencia y un signo de ausencia» ${ }^{25}$ que aparece en un momento de grandes cambios para dejar constancia de ellos y de su desaparición. Su ejecutor sería el fotógrafo-cazador que, armado con su cámara, va captando furtivamente a las personas y a la naturaleza, haciéndolos partícipes de la mortalidad y mutabilidad desde la distancia. La cámara les confiere «una suerte de pasaporte que aniquila las fronteras morales y las inhibiciones sociales, y libera al fotógrafo de toda responsabilidad ante la gente retratada», porque "no se interviene en su vida, solo se está de visita» ${ }^{26}$. De modo que, la relación entre fotógrafo y sujeto fotografiado se basa en la discreción.

En otro orden de cosas, si bien es cierto que 'una imagen dice más que mil palabras', y que las imágenes posibilitan el acceso democrático a la información; también es cierto que muchas veces se requiere de un pequeño comentario que contextualice aquello que muestran, puesto que la fotografía es algo más que estética. Pensamos, por ejemplo, en los grandes tomos de fotógrafos conocidos en los que vemos muchas imágenes de personas, lugares, guerras, mítines... que, por encontrarnos en otro contexto, no nos transmiten información alguna (pues podemos no ser capaces de identificar el evento) ni nos sugieren nada estético (pues puede que su pretensión fuera meramente informativa). De ahí la importancia del pie de foto y de su capacidad para contextualizar.

En definitiva, la fotografía no es más, como afirma Emmet Gowin, que «una herramienta para tratar con cosas que todos conocemos pero a las que nadie presta atención $»^{27}$.

Por otro lado, tiene una relación compleja con el tiempo. En primer lugar, su grandeza reside en poder captar la realidad huidiza en una fracción de segundo mediante el reconocimiento simultáneo del significado de un hecho

\footnotetext{
[24] Ibídem, p. 187.

[25] Ibídem, p. 25.

[26] Ibídem, p. 63.

[27] Ibídem, p. 196.
}

THÉMATA. Revista de Filosofía, $\mathrm{N}^{\circ} 51$ enero-junio (2015) pp.: 227-246 doi: 10.12795/themata.2015.i51.12 
y de la organización rigurosa de las formas; y, en segundo lugar, si bien el acto de fotografiar es momentáneo, la foto no se obtiene hasta más tarde, cuando el momento irrepetible ya ha pasado.

Ciertamente, esta idea es un tanto anacrónica porque, hoy en día, con las cámaras digitales, el momento de la captura y el de la primera visualización son correlativos: ambos dependen del simple movimiento de un botón. No obstante, aún hay que esperar para el revelado y para el retoque.

El retoque fotográfico no es algo exclusivo de la era digital; lo analógico era susceptible de manipulación en el momento de la impresión. Pero, sea como fuere, el instante decisivo sigue siendo ese preciso momento en el que todo converge de una forma perfecta: un instante que dura una fracción de segundo, y que ningún retoque o revelado podrá devolvernos jamás. Así, la fotografía es, por un lado, un arte del instante que requiere, por otro lado, de cierto tiempo (posterior) para su acabado.

Otra idea recurrente es la relacionar de la fotografía con los sistemas capitalistas. La primera razón es que fue un invento prácticamente contemporáneo a la Revolución Industrial, que conlleva en sí misma la reproductibilidad y la copia, características propias de la fotografía.

En segundo lugar, podría decirse que «una sociedad capitalista requiere una cultura basad en las imágenes» para "procurar muchísimo entretenimiento con el objeto de estimular la compra y anestesiar las heridas de clase, raza y sexo», así como para "acopiar cantidades ilimitadas de información para poder explotar mejor los recursos naturales, incrementar la productividad, mantener el orden.... ${ }^{28}$. Esto se debe a que la cámara cumple perfectamente la función de subjetivar la realidad a la vez que la objetiva, porque define la realidad tanto como espectáculo para las masas como objeto de vigilancia para los gobernantes.

En consecuencia, la razón última de la necesidad de fotografiarlo todo reside en la lógica del consumo, que «implica quemar, agotar; y, por lo tanto, la necesidad de reabastecimiento» ${ }^{29}$. Las fotografías, al 'traficar' con la fantasía y la información, se convierten en una «herramienta indispensable de la nueva cultura de masas» ${ }^{30}$.

Otro gran exponente que manifiesta la democratización de la fotografía es la figura del fotógrafo porque, si bien no todo el mundo puede ser pintor, o poeta, la fotografía permite, con el simple presionar de un botón, que cualquiera puede convertirse en 'fotógrafo' (o, mejor, que cualquiera pueda hacer fotografías).

El hecho de que la fotografía dependa del sujeto-fotógrafo la hace alejar-

[28] Sontag, S.: op. Cit., p. 173.

[29] Ibídem, p. 174.

[30] Ibídem, p. 75.

THÉMATA. Revista de Filosofía, $\mathrm{N}^{\circ} 51$ enero-junio (2015) pp.: 227-246

doi: 10.12795/themata.2015.i51.12 
se de la objetividad que se le pretende. Aún cuando intenta reflejar la realidad, el fotógrafo se deja influenciar por sus propios gustos y por su conciencia; porque, con sus decisiones, inevitablemente impone pautas a su modelo. Además, gracias a la gran variedad de temas que pueden ser fotografiados, el fotógrafo deja constancia de sus gustos según aquello que decide fotografiar. De algún modo, se ha asumido el mandato surrealista según el cual todo tema tiene el mismo peso; de modo que la fotografía ha acabado desarrollando afición incluso por temas como la basura, los desechos, los kitsch...

El fotógrafo necesita un hábito de visión que le permita contemplar la realidad como un despliegue de fotografías potenciales que enajenan la naturaleza, en vez de unirlo a ella. Por tanto, la visión fotográfica es disociativa, un hábito subjetivo que se afianza por las discrepancias entre la forma de ver del ojo y la de la cámara, y que se encarga de testimoniar que 'todo fluye', que nada se repite.

En definitiva, el fotógrafo es aquel que, «en el movimiento continuo de las apariencias y en la confusión de los acontecimientos que se suceden sin fin y siempre de forma inesperada, permanece alerta ${ }^{31}$.

\section{2. «La reproducción fotográfica de obras de arte como una fase de lucha entre la fotografía y la pintura $»^{32}$.}

En la cita que da título a este apartado se observan tres puntos claves a desarrollar: el enfrentamiento entre fotografía y pintura; la relación entre reproductibilidad técnica y fotografía; y los cambios sociales que conlleva la fotografía con respecto a la forma de entender el arte y su exclusividad.

En primer lugar, trataremos el enfrentamiento entre pintura y fotografía que, al parecer, tiene una razón de ser bastante sencilla de determinar: la mímesis; es decir, esta controversia que apareció junto al invento fotografía tiene que ver con aquello de que 'el arte tiene que imitar la naturaleza'. En el siguiente apartado debatiremos si es o no arte la fotografía; pero cabrá suponer que efectivamente lo es, sino no tiene sentido el enfrentamiento al que aludimos.

Para Walter Benjamin este enfrentamiento estaba destinado al fracaso desde sus inicios, porque no es más que una fase del enfrentamiento entre el arte y la técnica, ya que la diferencia entre el fotógrafo y el artista plástico no depende tanto del realismo de sus obras, sino del «mayor grado de técnica mecanizada, compatible con su actividad artística ${ }^{33}$.

Si sostenemos que arte es imitación de la naturaleza sostendremos, por consiguiente, que la fotografía es la forma más perfecta de arte. Pero fotografía y pintura, a parte de poder dedicarse a los mismo temas, no tienen por qué

[31] Ibídem, p. 51.

[32] Benjamin, W.: op. cit., p. 117.

[33] Benjamin, W.: op. Cit., p. 139.

THÉMATA. Revista de Filosofía, Nº51 enero-junio (2015) pp.: 227-246 doi: 10.12795/themata.2015.i51.12 
pretender sustituirse la una a la otra.

Ambas representan aquello que podemos observan (paisajes, escenas familiares, personas...), pero valiéndose de diferentes procedimientos que no tiene nada que ver y que, por tanto, tampoco se pueden comparar. La fotografía, generalmente, sería la encargada de captar el instante decisivo e irrepetible. La pintura, en cambio, se elabora con tiempo y paciencia; según Lhote, «de un pintor sólo se espera que realice una 'fotografía a mano'» ${ }^{34}$.

La fotografía, además, ofrece «la primera imagen del encuentro entre la máquina y el hombre» ${ }^{35}$, porque hace uso de la máquina, que no es necesaria para el pintor. No obstante, cabe recordar que «la fotografía no es una simple reproducción mecánica de la realidad, sino que un operador de carne y hueso se encuentra tras la cámara» ${ }^{36}$.

La fotografía, generalmente, requiere movimiento, observación activa y despierta de lo que nos rodea. La pintura parece más bien una sensibilidad estética fruto de lo que nuestra consciencia a captado de un instante. Por tanto, la foto es una acción inmediata; mientras que el dibujo requiere meditación.

Con todo ello, destacar el hecho de que la fotografía liberó la mano del hombre en los procesos de reproducción plástica; y, «como el ojo es más rápido captando que la mano dibujando, el proceso de reproducción plástica se aceleró tan enormemente que llegó a ir al paso de la palabra hablada» ${ }^{37}$. Pero eso no impide que la fotografía pueda ser «un modo de expresión por sí mismo, una modalidad artística a la altura de la pintura ${ }^{38}$.

Puede que estos argumentos sean vagos (porque siempre se pueden encontrar los rasgos que hemos determinado para la pintura, en la fotografía, y viceversa) y muy generales, pero la única pretensión al hacer uso de ellos es mostrar que, aquella lucha controvertida que apareció en los orígenes de la fotografía, hoy no es tan relevante como lo pudo ser entonces. No son más que dos formas diferentes de decir lo mismo (o algo parecido) que se complementan más de lo que se excluyen: la fotografía es una forma más rápida de reproducir el mundo; la pintura es la forma tradicional que se sintió amenazada ante el progreso.

Algunos dicen que la fotografía liberó a la pintura de la «monótona faena de la fiel reproducción», permitiéndole "perseguir una tarea más elevada: la abstracción $»^{39}$. Pero, lejos de suceder esto, la pintura se dejó influenciar por la fotografía imitando los efectos realistas de la misma. Así, paradójicamente, la

[34] Chéroux, C.: op. cit., p. 16.

[35] Benjamin, W.: op. cit., p. 126.

[36] Chéroux, C.: op. cit., p. 35.

[37] Benjamin, W.: op. Cit., 94.

[38] Chéroux, C.: op. cit., p.23.

[39] Sontag, S.: op. cit., p. 143.

THÉMATA. Revista de Filosofía, No 51 enero-junio (2015) pp.: 227-246 doi: 10.12795/themata.2015.i51.12 
fotografía (más barata y accesible) ha permitido a la pintura elevarse a eso que popularmente se entiende como 'arte': algo distante e inaccesible, tradicionalmente exclusivo de la aristocracia.

Por otro lado, la fotografía tiene una posición ventajosa a este respecto porque puede transcribirse a la pintura: mirar pinturas puede ayudarnos a ver mejor las fotografías, pero no al revés. La mayoría de las obras de arte son conocidas gracias a sus copias fotográficas, de modo que la fotografía a transformado las bellas artes y las normas tradicionales del gusto; así como la idea de obra de arte, en la que pierde fuerza la idea de 'objeto original realizado por un artista individual' y, por consiguiente, la idea de autor.

Pero, sin duda, lo que más aleja a la pintura de la fotografía es la técnica, hasta el punto de que, como afirma Moholy-Nagy, sus límites son difíciles de predecir. En cambio, Benjamin sostiene que el esplendor de la fotografía se produjo durante el primer decenio de su existencia, antes de que se industrializara. Si bien hubo quien supo ver las ventajas (incluso aplicables a la ciencia) de esta nueva forma de arte, otros creyeron estar presenciando el fin del mismo, aplastado por la técnica, que «puede conferir a sus productos un valor mágico que una imagen pintada ya nunca tendrá» ${ }^{40}$.

Benjamin parece quitarle importancia al hecho de la reproductibilidad técnica afirmando que "la obra de arte ha sido siempre fundamentalmente susceptible de reproducción. Lo que los hombres habían hecho podía ser siempre imitado por los hombres» ${ }^{41}$. Según el autor, los métodos de reproducción mecánica son simples técnicas reductoras que permiten tener un dominio «sobre las obras sin el que no pueden llegar a ser disfrutadas» ${ }^{42}$.

No obstante, Benjamin establece una diferencia entre la reproducción técnica y la manual: la reproducción manual tiene menos autoridad que la obra original; mientras que esto no sucede en la reproducción técnica, puesto que permite (en el caso de la fotografía) destacar, por un lado, partes concretas del original (poco accesibles al ojo humano) y, por otro, que la copia llegue a contextos inasequibles para el original. A pesar de esto, también admite que en la reproducción se pierde lo más importante del original: la noción de autenticidad fundada en "el aquí y el ahora de la obra de arte, su existencia irrepetible en el lugar en que se encuentra ${ }^{43}$.

El autor lleva un poco más lejos esta idea afirmando que el valor de testimonio histórico propio del original se tambalea en la reproducción que «sustituye la ocurrencia irrepetible de lo reproducido por su ocurrencia masiva ${ }^{44}$.

[40] Ibídem, p. 26.

[41] Ibídem, p. 93.

[42] Ibídem, p. 18.

[43] Ibídem, p. 95.

[44] Ibídem, pp. 96-97.

THÉMATA. Revista de Filosofía, No 51 enero-junio (2015) pp.: 227-246 doi: 10.12795/themata.2015.i51.12 
La obra de arte reproducida se va convirtiendo, cada vez más, en la reproducción de una obra de arte dispuesta para ser reproducida. Este cambio en el criterio de autenticidad en la producción plástica produce también importantes cambios en la función social del arte, que ya no se fundamenta en el ritual sino en la política, y que requiere de la exhibición, que ha dotado a la obra de arte de funciones nuevas, capaces de relegar algún día su función artística a un segundo plano.

En definitiva, defender el impacto social de la fotografía que, ya en 1907, algunos autores fueron capaces de matizar: «'ninguna obra de arte se contempla en nuestro tiempo con tanta atención como los retratos de uno mismo, de los parientes próximos y amigos, y de la amada' ${ }^{45}$. Con esta frase, Lichtwark subrayó el desplazamiento de la investigación desde las distinciones estéticas hacia las funciones sociales. Otros autores han apuntado que los debates se han centrado en 'la fotografía en cuanto arte', alejándose del hecho social del 'arte como fotografía', cuando la reproducción fotográfica de obras de arte ha repercutido más sobre la función del arte que la configuración más o menos artística de la fotografía.

Los pies de foto también influirán en este cambio de la función social del arte, pues son considerados el «componente crítico de la fotografía» ${ }^{46}$.

\section{3. ¿Es arte la fotografía? Redefinición del concepto de lo bello.}

«En un primer momento se malgastó mucha agudeza en decidir si la fotografía era o no un arte, sin haberse planteado previamente si la invención de la fotografía no había cambiado el carácter global del arte» ${ }^{47}$; es decir, la pregunta por la pertenencia o no de la fotografía al arte está, cuanto menos, mal planteada.

El concepto de arte ya es bastante difícil de definir y delimitar, pero básicamente puede definirse o bien como "cierta virtud o habilidad para hacer o producir algo» ${ }^{48}$, o bien usando el concepto de mímesis, el "arte imita de algún modo la naturaleza» ${ }^{49}$.

En primer lugar apuntar que, en el momento de la aparición de las primeras cámara, allá por el año 1840, en Francia e Inglaterra, cuando aún no habían fotógrafos profesionales (y, por tanto, tampoco aficionados), ni la fotografía tenía una función social clara, ni era considerada una actividad artística. Sólo posteriormente, con la industrialización, se le confirió cierta utilidad

[45] Ibídem, p. 48.

[46] Ibídem, pp. 83-84.

[47] Benjamin 2013, p. 108.

[48] Ferrater Mora, J., Diccionario de Filosofía, Círculo de lectores, Barcelona, 2004, p. 246.

[49] Ferrater Mora, J.: op. cit., p. 247.

THÉMATA. Revista de Filosofía, $\mathrm{N}^{\circ} 51$ enero-junio (2015) pp.: 227-246

doi: 10.12795/themata.2015.i51.12 
social y aparecieron las dudas sobre su condición de arte.

¿Es arte la fotografía? ¿Es un medio mecánico para el cual (y más hoy en día) no hay que tener cualidades especiales? Hay quien se mostrará partidario de la primera opción; y hay quien defenderá la segunda, y con razón, ya que se ha aludido varias veces al carácter democrático de la fotografía. Pero esto parece más una democratización del arte en general, de la posibilidad de ser 'artista', que sólo de la fotografía.

Partidarios de esta segunda opción parecen ser los creadores de la Kodak que, ya en una anuncio de 1888, apuntaban que la fotografía es un arte tan accesible que en él todo el mundo puede ser artista, fotógrafo: «las fotografías no parecen depender en exceso de las intenciones del artista ${ }^{50}$, sólo hay que apretar un botón y la cámara hace el resto. «En el cuento de hadas de la fotografía, la caja mágica asegura la veracidad y elimina el error, compensa la inexperiencia y recompensa la inocencia $»^{51}$.

En consecuencia, definir la fotografía como arte o como algo meramente técnico es una tarea compleja que sólo acepta una solución conciliadora: definir la fotografía de múltiples formas. De este modo, habrá fotografía que podrá considerarse arte (para la cual deberán existir ciertos criterios pre-establecidos); habrá otra que será meramente informativa (la periodística); otra para guardar recuerdos; otra que simplemente no dirá nada... La pertenencia de cada fotografía a una definición u otra dependerá, muchas veces, de la mirada subjetiva del individuo que a ellas tenga acceso.

Así, la pregunta sobre si es o no arte la fotografía es equívoca en sí misma porque, «aunque la fotografía genera obras que pueden considerarse arte [...] no es en absoluto una disciplina artística», puesto que, desde el principio, "se ha presentado a esa noción del arte que proclama que el arte es obsoleto» ${ }^{52}$. Pero la fotografía, sin ser propiamente un género de arte, tiene la capacidad de transformar todos sus temas en obras de arte. Por ello, «más importante que la cuestión de si la fotografía es o no es arte es el hecho de que la fotografía pregona (y crea) nuevas ambiciones para las artes» ${ }^{53}$. Si bien las artes tradicionales son elitistas, la fotografía es democrática: no hay autor, el mundo entero es tema, y carece de contenido. Por consiguiente, «ahora todo arte aspira a la condición de fotografía» ${ }^{54}$.

Parece ser que, originariamente, la controversia se centró en «la cuestión de la fidelidad de la fotografía a las apariencias y su dependencia de una

[50] Sontag, S.: op. Cit., p. 59.

[51] Ídem.

[52] Ibídem, p. 146.

[53] Ibídem, p. 147.

[54] Ibídem, p. 148.

THÉMATA. Revista de Filosofía, No 51 enero-junio (2015) pp.: 227-246 doi: 10.12795/themata.2015.i51.12 
máquina como impedimento para ser un arte refinado» ${ }^{55}$. Pero los fotógrafos defendieron, frente a estas acusaciones, que era una práctica vanguardista contraria a las pautas de visión ordinarias; así, de acuerdo con Henry Peach Robinson, "fotografiar es un arte porque puede mentir»" ${ }^{56}$.

Este argumento es bastante sólido porque, aunque la fotografía, supuestamente, muestre la realidad tal como es mejor que cualquier otro arte, también puede ser manipulada. No obstante, de acuerdo con Edward Weston, «sólo con esfuerzo se puede obligar a la cámara a mentir» ${ }^{57}$.

Parece que estas dos ideas no son necesariamente incompatibles: la fotografía puede mentir tanto como reproducir la realidad con fidelidad. Así, la pregunta por cuál de estas dos opciones la convierte en arte deja de ser relevante, pues «la fotografía es, por su misma naturaleza, una manera promiscua de ver, y en manos talentosas un medio de creación infalible» ${ }^{58}$. Por lo tanto, será arte dependiendo de quién y de cómo se fotografíe.

La fotografía tiene, como el arte pop, la capacidad de tranquilizar a los espectadores asegurándoles que el arte no es difícil. Posibilita, de este modo, una postura radical frente al arte tradicional, que es «reaccionario, elitista, esnob, insincero, artificial, desvinculado de las grandes verdades de la vida diaria", y lo transforma «en documento cultural $»^{59}$. No obstante esta postura, al pasar a ser considerada la fotografía "una actividad noble y exaltada» (es decir, un arte), también ha adquirido las inseguridades y ansiedades del arte ingenuo, así como su comodín: «que se continúe honrando sus veladas pretensiones de refinamiento» ${ }^{60}$.

Con ello, la fotografía pasa a formar parte de los museos, adquiriendo su estatus de 'arte' gracias al gusto moderno por una definición abierta del mismo. Es presentada en el museo como un conjunto de intenciones y estilos simultáneos que no se perciben como contradictorios, aunque son diferentes. Pero esta intromisión en los museos la transforma en un estudio de sus propias posibilidades, de modo que se hacen fotografías por encargo, con propósitos prácticos... perdiéndose así su función ingenua o descriptiva.

Cabe recordar la poco importancia que tiene la figura del autor: cuanto más grande y variada sea su obra, más parecerá adquirir una especie de autoría colectiva. Es decir, el tema siempre se impone, de modo que la firma no es posible debido a la gran variedad de los mismos. El hecho de que todo pueda ser usado como tema implica que hay belleza o interés en todo si se mira con ojo perspicaz, lo que permite determinar casi cualquier fotografía como arte. Es lo

[55] Ibídem, p. 126.

[56] Ibídem, p. 127.

[57] Ibídem, p. 181.

[58] Ibídem, p. 128.

[59] Ibídem, p. 130.

[60] Ibídem, p. 131.

THÉMATA. Revista de Filosofía, $\mathrm{N}^{\circ} 51$ enero-junio (2015) pp.: 227-246 doi: 10.12795/themata.2015.i51.12 
que manifestamos cuando afirmamos que 'eso da para una fotografía', que todo deber ser visto o registrado.

No obstante, Sontag plantea la posición opuesta: «para ser legítima como arte, la fotografía debe cultivar la noción del fotógrafo como auteur, y de que todas las fotografías realizadas por el mismo individuo configuran un corpus ${ }^{61}$. La intención parece aceptable: todas las artes se refuerzan en la figura del autor; pero los argumentos opuestos parecen más rotundos: un fotógrafo puede tocar tantos temas que sería difícil reconocer una fotografía suya sin tener conocimiento previo de que ésta existe.

Por otro lado, y a diferencia de otras artes, el decantarse por una fotografía u otra no depende necesariamente de la superioridad formal de la misma, sino del gusto del espectador. No obstante, en la modernidad parece que la fotografía está tomando un rumbo formalista; por un breve período de tiempo "pareció que se había erigido un punto de vista para la evaluación de las fotografías: iluminación impecable, maestría de composición, claridad temática...» ${ }^{62}$, aunque esta postura no duró mucho. «La nueva posición procura liberar la fotografía como arte de las normas opresivas de la perfección técnica» y de la belleza, abriendo «la posibilidad de un gusto global para el que ningún tema (ni su ausencia) o técnica (ni su ausencia) bastaría para descalificar una fotografía» ${ }^{63}$.

"Como la fotografía tiene al mundo por tema, hay espacio para toda suerte de gustos [...] en fotografía, el eclecticismo no tiene límites» ${ }^{64}$, por lo que no se puede excluir ningún canon. Por esta posibilidad del gusto global, la fotografía borra la diferencia entre buen gusto y mal gusto. De acuerdo con Les Levine, la intención de los «artistas de la cámara es elevar el arte más allá del mero nivel del gusto», despojando al mismo de toda lógica «para que el espectador le aplique su lógica propia y la obra, en realidad, se haga ante los ojos del espectador ${ }^{65}$.

La fotografía como arte, además, se caracteriza por la falta de un vocabulario que no peque de juicios vagos o engañosos. La innovación y la presencia (el aquí y el ahora) sí son consideradas, por ciertos autores, criterios de evaluación que introducen nuevos esquemas formales y cambios en el lenguaje visual.

Respecto a la relación especial de la fotografía con la modernidad, apuntar que "una sociedad llegue a ser 'moderna' cuando una de sus actividades principales es producir y consumir imágenes» ${ }^{66}$. También se la puede rela-

[61] Ibídem, p. 136.

[62] Ibídem, p. 135.

[63] Ídem.

[64] Ibídem, p. 141.

[65] Ibídem, p. 189.

[66] Ibídem, p. 149.

THÉMATA. Revista de Filosofía, No 51 enero-junio (2015) pp.: 227-246

doi: 10.12795/themata.2015.i51.12 
cionar con el capitalismo y las mercancías: «la pretensión de que la fotografía [sea] un arte es contemporánea de su aparición como mercancía», lo cual es una «ironía dialéctica» porque, si bien iba "a poner en tela de juicio el concepto mismo de obra de arte al acentuar su carácter de mercancía mediante su producción ${ }^{67}$, acaba calificándose de artística.

Por otro lado, podemos afirmar que, con la fotografía, sucede lo mismo que decía Wittgenstein respecto de la palabra: su significado es el uso. Por eso mismo, «la presencia y proliferación de todas las fotografías contribuye a la erosión de la noción misma de significado» ${ }^{68}$. Así, las fotografías cambian según el contexto en que se las vea, y se vuelven más interesantes al distanciarse de las intenciones originarias del autor. Por tanto, «no es del todo erróneo afirmar que no existe una mala fotografía, sino sólo fotografías menos interesantes» ${ }^{69} \mathrm{y}$ que «el tiempo termina por elevar casi todas las fotografías, aun las más inexpertas, a la altura de arte» $^{70}$.

Pero también hay quien considera, como Cartier-Bresson, que la fotografía no es 'Arte' porque depende de la intuición del momento y no de la reflexión. La fotografía «debe de ser la única actividad productora de obras de arte acreditadas en que basta un simple movimiento, una presión digital, para obtener una obra completa ${ }^{71}$.

La segunda definición dada del arte se refería a la mímesis. Partiendo de la idea de que el arte tiene que imitar la realidad, no habrá arte más propicio para este fin que la fotografía. Pero hay quien no cree que ésta sea su finalidad, como es el caso de Baudelaire:

«Puesto que la fotografía nos otorga todas las garantías de exactitud que puedan desearse (¡lo creen de veras, los insensatos!), entonces fotografía y Arte son la misma cosa'. Desde ese momento, nuestra sociedad inmunda se abalanzó como un Narciso a contemplar su imagen trivial en el metal [...]. Algún escritor democrático debió de haber visto en ello un método barato para difundir el odio por la historia y la pintura entre las gentes» ${ }^{72}$.

En definitiva, las posibilidades son variadas y las opiniones distintas. No tiene sentido plantear si algo es arte si no está claramente definido el concepto de Arte; pero si reparamos en la consideración que tiene la fotografía hoy en día (la posibilidad de ser fotógrafo profesional, de ver exposiciones de fotografía en museos, de alterar nuestra percepción estética...) gracias, posiblemente, a su condición de mercancía en un mundo capitalista, no podemos

[67] Benjamin, W.: op. Cit., p. 79.

[68] Sontag, S.: op. cit., p. 109.

[69] Ibídem, p. 139.

[70] Ibídem, p. 30.

[71] Ibídem, p. 160

[72] Ibídem, p. 185.

THÉMATA. Revista de Filosofía, $\mathrm{N}^{\circ} 51$ enero-junio (2015) pp.: 227-246 doi: 10.12795/themata.2015.i51.12 
dejar de afirmar que algo de lo que hoy se entiende por arte sí se encuentra en la fotografía: por ejemplo, su relación con el surrealismo (que libera a la imaginación y reformula el imaginario, promoviendo una fuerte crítica de los valores burgueses) y el uso de la composición formal, propia de la geometría.

Según Susan Sontag, la fotografía es surrealista por la distancia social y temporal que impone y franquea. Participa del surrealismo en tanto que es el «arte de generalizar lo grotesco y luego descubrir los matices (y los encantos) de $e s o{ }^{73}$. Es más, aunque es capaz de "emitir un juicio reaccionario», también es capaz de "transformar la historia en una mera acumulación de extravagancias ${ }^{74}$. En la difundida costumbre de poner fotografías en las paredes de salones y dormitorios, también ve Sontag una clara manifestación de la difusión del gusto surrealista, pues las «fotografías satisfacen muchos de los criterios aprobados por el surrealismo, ya que son objetos ubicuos, baratos, anodinos» que, «cuando se ajan, ensucian, manchan, resquebrajan y palidecen, conservan un buen aspecto», e incluso "a menudo mejoran» ${ }^{75}$.

Pero el problema más grande que surge tras esta intención surrealista de darnos un punto de vista nuevo para la crítica de la cultura moderna es que sólo ha conseguido que los acomodados tomen fotografías de la miseria social que los rodea con el objetivo de documentar una realidad oculta para ellos. Mediante esa forma de observar la realidad del otro con curiosidad y distancia, parece como si la fotografía trascendiera los intereses de clase.

Esto lo único que demuestra es un desplazamiento de la forma de enfrentarse a la realidad: si bien en el pasado el desconsuelo para con la realidad se expresaba mediante el anhelo de otro mundo; en la modernidad, este anhelo se expresa reproduciendo este mundo, «como si sólo por mirar la realidad en la forma de un objeto [...] fuera de veras real, es decir, surreal» ${ }^{76}$. Esto implica cierta condescendencia para con la realidad, porque las cosas pasan de estar 'ahí fuera' a estar 'dentro' de la fotografía. Por tanto, los fotógrafos, «trabajando dentro de los términos de la sensibilidad surrealista, insinúan la vanidad de intentar siquiera comprender el mundo y en cambio nos proponen que lo coleccionemos» ${ }^{77}$.

La otra característica que podría relacionar la fotografía con el arte sería la composición. No todos los autores dan la misma importancia a este componente, pero podría ser uno de esos patrones que marcan diferencias entre una buena fotografía y una mala, una fotografía profesional o amateur... Ésta será una de las pocas características que permitan establecer diferencias y clasificaciones en fotografía, pues «la diferencia entre una fotografía buena y

[73] Ibídem, p. 80.

[74] Ídem.

[75] Ibídem, p. 84.

[76] Ibídem, p. 85.

[77] Ibídem, p. 87.

THÉMATA. Revista de Filosofía, No 51 enero-junio (2015) pp.: 227-246 doi: 10.12795/themata.2015.i51.12 
otra mediocre es cuestión de milímetros» ${ }^{78}$.

Así pues, «la composición debe ser una de nuestras preocupaciones constantes, pero en el momento de fotografiar sólo puede ser intuitiva, porque nos enfrentamos a instantes fugaces ${ }^{79}$. Por tanto, la parte que forma la cualidad geométrica de la imagen es premeditada; mientras que hay otra, tal vez la más importante, que corresponde únicamente al azar.

No obstante, y como no podía ser de otro modo, encontramos posiciones contradictorias: la fotografía, para unos, es un instrumento para conocer las cosas cuyas cualidades formales tiene una importancia secundaria: sólo importa qué es lo fotografiado; mientras que, para otros, como por ejemplo "para Cartier-Bresson, hacer fotografías es 'hallar la estructura del mundo, regodearse en el placer puro de la forma' ${ }^{80}$. Pero la organización rigurosa de las formas es sólo la condición previa de una imagen articulada; la imagen, además, debe decir algo, debe unirlo todo: forma y emoción. A fin de cuentas, como afirma Louis Figuier, "lo que hace al artista es el sentimiento y no el procedimiento"»"

Por todo ello, estas controversias y cambios conceptuales que conlleva la aparición de la fotografía para al arte, no podrían más que venir acompañados de una redifinición del concepto de belleza.

Las fotografías se han convertido en la medida de lo bello, pues «salvo en aquellas situaciones en las cuales la cámara se utiliza para documentar [...] lo que mueve a la gente a hacer fotografías es el hallazgo de algo bello» ${ }^{82}$. Por ello, la gente se pone nerviosa cuando van a fotografiarla: temen que la cámara no les muestre toda la belleza que esperan. Pero que las fotografías sean a menudo elogiadas por su veracidad indica que, la mayoría, en realidad no lo son; de ahí la importancia del retoque, que empezó a utilizarse en 1855 y que hoy ha alcanzado cumbres insospechadas gracias a los ordenadores.

Así, la fotografía lidia con el embellecimiento, que lo relaciona con las bellas artes, y la veracidad, que puede ser manipulada. Por ello, la fotografía no reproduce el mundo de forma fidedigna, como se creía en sus orígenes; sino que, más bien, ensalza las apariencias y se limita a representar los diferentes puntos de vista. En definitiva, las fotografías no sólo muestran lo que hay, sino lo que uno ve.

De este modo, lo bello pasó a ser, básicamente, aquello que «el ojo no ve o no puede ver: la visión fracturada, desconcertante, que sólo ofrece una cámara ${ }^{83}$. La fotografía rompe la sosegada relación entre Naturaleza y Belleza intemporal; ahora se pretende mostrar el desorden frente a las tradicionales

[78] Cheróux, C.: op. Cit., p. 144.

[79] Ibídem, pp. 133-134.

[80] Sontag, S.: op. cit., p. 104.

[81] Benjamin, W.: op. cit., 131.

[82] Sontag, S.: op. cit., p. 89.

[83] Ibídem, p. 95.

THÉMATA. Revista de Filosofía, No 51 enero-junio (2015) pp.: 227-246 doi: 10.12795/themata.2015.i51.12 
formas tranquilizadoras. De este modo, la fotografía acaba por embellecer lo humilde, lo feo, convirtiendo el pathos de lo real en el pathos de la belleza.

El logro de los fotógrafos es, por tanto, mostrar que la belleza está en todas partes, que no es inherente a nada. La cámara es capaz de mostrar otro tipo de belleza, porque el efecto principal que persigue la fotografía es convertir el mundo en un sitio tal en que cualquier cosa puede ser objeto de consumo en tanto que objeto de apreciación estética.

Sea como fuere, aquello que tienen en común las cosas cuando se las ve como fotografías es su pretensión humanista de explicarle el hombre al hombre. Pero la fotografía no explica, reconoce; con lo que, tanto esta cualidad humanista, como la de ser algo interesante para ser fotografiado, son huecas: la fotografía es reduccionista tanto cuando intenta ser informativa como cuando pretende mostrar formas bellas.

En definitiva, «la fuerza de una fotografía reside en que preserva abiertos al escrutinio instantes que el flujo normal del tiempo reemplaza inmediatamente» ${ }^{84}$. Esto ha producido nuevos cánones de belleza, pues «la capacidad de la cámara para transformar la realidad en algo bello deriva de su relativa debilidad como medio para comunicar la verdad $\rangle^{85}$. Por lo tanto, hay cierta confusión, subyacente a la empresa fotográfica, entre verdad y belleza.

\section{Sus nuevas formas.}

Para terminar, hacer una rápida mención a la fotografía digital, como fin necesario que alcanzar para el arte de la técnica; y al cine que, por ser imagen en movimiento, es consecuencia necesaria de la imagen fija.

La fotografía digital ha democratizado más, si cabe, la fotografía: la normalización del retoque, por ejemplo, permite no sólo que cualquiera puede hacer fotografía, sino que incluso aquellos que no tienen cualidades para la misma, gracias a unos simples ajustes, conviertan una foto que no dice nada en algo significativo.

En segundo lugar, si bien es cierto que el instante decisivo sigue siendo insustituible, también lo es que, el hecho de poder comprobar in situ cómo ha quedado la fotografía, permite que pueda volver a realizarse en el caso de no ser satisfactoria.

No obstante, al igual que la invención de la fotografía tuvo sus adversarios, este nuevo progreso también tiene sus enemigos. Si la fotografía ya se distanció desde un primer momento de la forma tradicional en que se entendía el arte, su digitalización no hace más que ampliar este distanciamiento irremediable; pero, ¿hasta cuándo será lícito considerarla un arte si sigue alejándose

[84] Ibídem, p. 114.

[85] Ídem.

THÉMATA. Revista de Filosofía, No51 enero-junio (2015) pp.: 227-246 doi: 10.12795/themata.2015.i51.12 
a este ritmo frenético de las formas tradicionales? ¿O a caso habrá que seguir ampliando un concepto de Arte cada día más sujeto a la técnica?

En último lugar, hacer una rápida mención al cine como forma de representación pictórica que, en definitiva, tiene sus orígenes en la fotografía. El cine no sería más, originariamente, que una rápida sucesión de fotografías que dan la sensación de estar en movimiento. De modo que el cine es difícilmente concebible sin la fotografía, de la cual es consecuencia necesaria, e implica grandes cambios y avances tanto en el Arte como en sus implicaciones sociales:

«Cuando estos aparatos se muestren en público, cuando todo el mundo pueda fotografiar a sus seres más queridos, no ya en su forma inmóvil, sino en su movimiento, en su acción, en sus gestos familiares, y con la palabra a punto de salir de los labios, la muerte dejará de ser absoluta» ${ }^{86}$.

[86] La Postre, 29 de diciembre de 1895, extracto de un rótulo en el Museu del Cinema de Girona.

THÉMATA. Revista de Filosofía, Nº51 enero-junio (2015) pp.: 227-246

doi: 10.12795/themata.2015.i51.12 


\section{Referencias bibliográficas:}

Sontag, S.: Sobre la fotografía, traducción de Carlos Gardini, Barcelona: Debolsillo, 2013.

Benjamin, W.: Sobre la fotografía, 'Algo nuevo acerca de las flores', 'Diario parisino (4 de febrero)', 'Una pequeña historia de la fotografía', 'Carta de París [2]: pintura y fotografía', 'Gisèle Freund', 'La obra de arte en la época de su reproductibilidad técnica (fragmento)', 'La fotografía', edición y traducción de José Muñoz Millanes, Valencia: Pre-textos, 2013.

Chéroux, C.: Herni Cartier-Bresson, el disparo fotográfico, traducción de Laura Collet Texidó, Barcelona: Blume, 2012.

Fundación Henri Cartier-Bresson: Henri Cartier-Bresson, ¿de quién se trata?, traducción de Marga Latorre, Barcelona: Lunwerg, 2003. 